\title{
SIMULATION MODELLING OF AERIAL WORKS AND ITS ROLE IN THE PREPARATION OF CONSTRUCTION
}

Andrej BISTÁK ${ }^{*}$, Zdenka HULÍNOVÁ', Michal NEŠTIAK²

\section{Abstract}

The construction process is characterized by a diverse technological composition and the use of a wide range of construction machinery and mechanization. The amount of machinery increases with the complexity of the construction, which increases the demands concerning the preparation and overall organisation of the construction. The preparation of construction processes carried out by helicopters (aerial work) must respect the effect of randomly changing construction conditions as well as the specific working conditions of helicopters. The complexity of such a system can be modelled using simulation models. In the work presented, we designed and practically tested a simulation model of aerial work in the MATLAB software environment. An essential part of the simulation model is an algorithm designed on the basis of commercial numerical weather prediction models. We consider the outputs of the simulation to be reliable, because they are very close to the actual results achieved in the case of the implementation of construction of this type. The concept of the simulation model enables its wider use not only in the construction sector, but also in other branches of industry.

\section{Address}

1 Dept. of Building Technology, Faculty of Civil Engineering, Slovak University of Technology in Bratislava, Slovakia

2 Slovak Hydrometeorological Institute, Bratislava, Slovakia

* Corresponding author: andrej.bistak@stuba.sk

\section{Key words}

- Simulation model,

- Helicopter,

- Construction processes,

- Pre-construction design,

- Numerical weather prediction,

- Logistics.

\section{INTRODUCTION}

Our society is currently in the midst of the Fourth Industrial Revolution, which is having a substantial impact on the nature of production and forms of work (Industry 4.0). In all industrial sectors, information technologies based on state-of-the-art computer technology are becoming dominant. A separate industry, i.e., the construction sector, is also responding to this development, albeit with some delays. There is a certain degree of inertia, especially in the construction production sector, which is probably due to the specific characteristics of construction production (work in an open workplace, relocation of production machinery, long production times, etc.), their variable complexity (from family houses to highways, railways, bridges and tunnels, up to skyscrapers reaching heights of hundreds of meters) and long building traditions.
There is a need for more thorough preparation of constructions, especially in the case of complex constructions, as it is still possible at this stage to significantly influence their course and form. Today, the rapid development of information technology has placed the power of advanced tools, once the domain of institutional mainframe computers, into laptops situated directly at the construction site. One of these tools is simulation modelling, a tool still often overlooked in the construction industry (AbouRizk 2010; AbouRizk et al. 2011; Hulínová 2011; Lee et al. 2013; Fedorko, Honus and Badiarová 2017). The possibilities of using simulation modelling in construction production have been discussed by several authors, e.g., Alsudairi (2015); Jung et al. (2016); Mahmoodzadeh and Zare (2016); Jung et al. (2017); Mačková et al. (2017); Muhabie et al. (2018); and Lindhard et al. (2019); nevertheless, the use of simulations in this area is still only sporadic. 


\section{MATERIALS AND METHODS}

Our research primarily uses and tries to appropriately apply principles of computer simulation in the preparation of construction projects (Martinez 2010; Hulínová 2011), which primarily means the development of a simulation model of the construction process carried out by helicopters (aerial work) and experimentation with such a model. The selection of a suitable construction process is crucial because the work with helicopters is so complicated that their preparation requires the use of simulation modelling.

Helicopters can fly in all directions and, unlike aeroplanes, they can stop in mid-air, i.e., hover. It is the combination of these characteristics that allows helicopters to be used in construction (Jindra 1965; Messingerová 2005). Since helicopters move in three-dimensional space during their work, their activities are significantly affected by weather conditions. The extent of this impact fluctuates and is therefore random (probabilistic). The use of simulation modelling is a good method for ascertaining the complex reality that is characteristic of aerial work, as it enables us to simulate the random nature of construction work (Hulínová 2011).

Using helicopters in construction work has a long tradition in our country; it was first carried out in the territory of the former Czechoslovakia in 1957 (Jindra 1965). In our conditions, installations of aerial cableways have become a significant driving force for the development of this area. The main initiator of the use of helicopters in construction work in our country was the former Czechoslovak company Transporta Chrudim, which manufactured these cableways and was interested in streamlining construction in demanding conditions, which was still poorly mechanized at the time (Hrubeš 1988). At present, aerial work is widely used, not only in inaccessible mountain terrains, but also in urban areas. They are mainly used in assembling and concreting processes.

\subsection{Main Principles}

In order to develop a simulation model, in-depth knowledge of the processes performed on a construction site, including the interrelationships and dependencies between them, is required. When creating a simulation model, it is necessary to proceed from the observation of construction sites, in this case construction sites using helicopters, as the model developed should reflect the reality of the course of these processes. When collecting data on construction sites, the method of work imaging is used (Hulínová 2011; Bisták 2017; Bisták 2018).

These starting points are necessary inputs for solving the main part of the work, i.e., creating your own simulation model. The proposed simulation model takes into account the randomly occurring phenomena, especially the weather conditions, which in this construction technology most affect the work of the helicopter, and thus affect its most important feature for the construction process, i.e., the maximum lift capacity of the helicopter (Dosoudil et al. 1971; Bartoš et al. 1973; Kadlec 2011). The simulation scheme (algorithm) is shown using the Business Process Model and Notation (BPMN) standard (Fig. 1); the simulation model itself is processed in the MATLAB programming environment (Fig. 2).

The degree of approximation to the actual conditions at the construction site depends on the degree of the reliability of the data that is entered into the simulation model. The core of the algorithm of the proposed model, which works with weather conditions, can be created in several ways; each method provides forecast data for different lengts of time (days, weeks, or months). However, in the case of using input data with the character of a long-term weather forecast, it is necessary to take into account the lower degree of reliability of the results obtained, which is related to the well-known fact that the success of a long-term weather forecast is lower compared to a shortterm forecast.

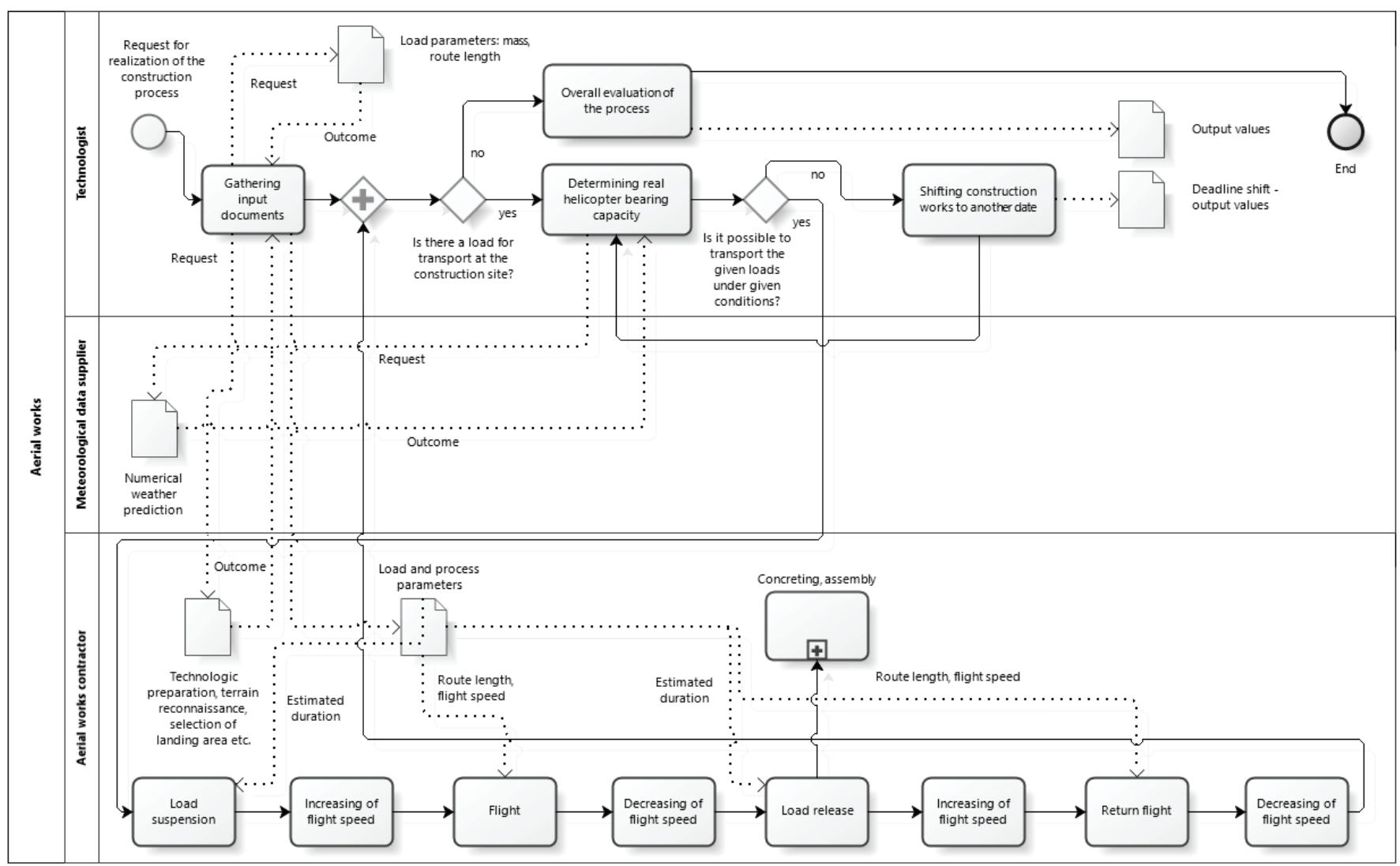

Fig. 1 Algorithm for implementation of aerial work using the BPMN method (authors) 


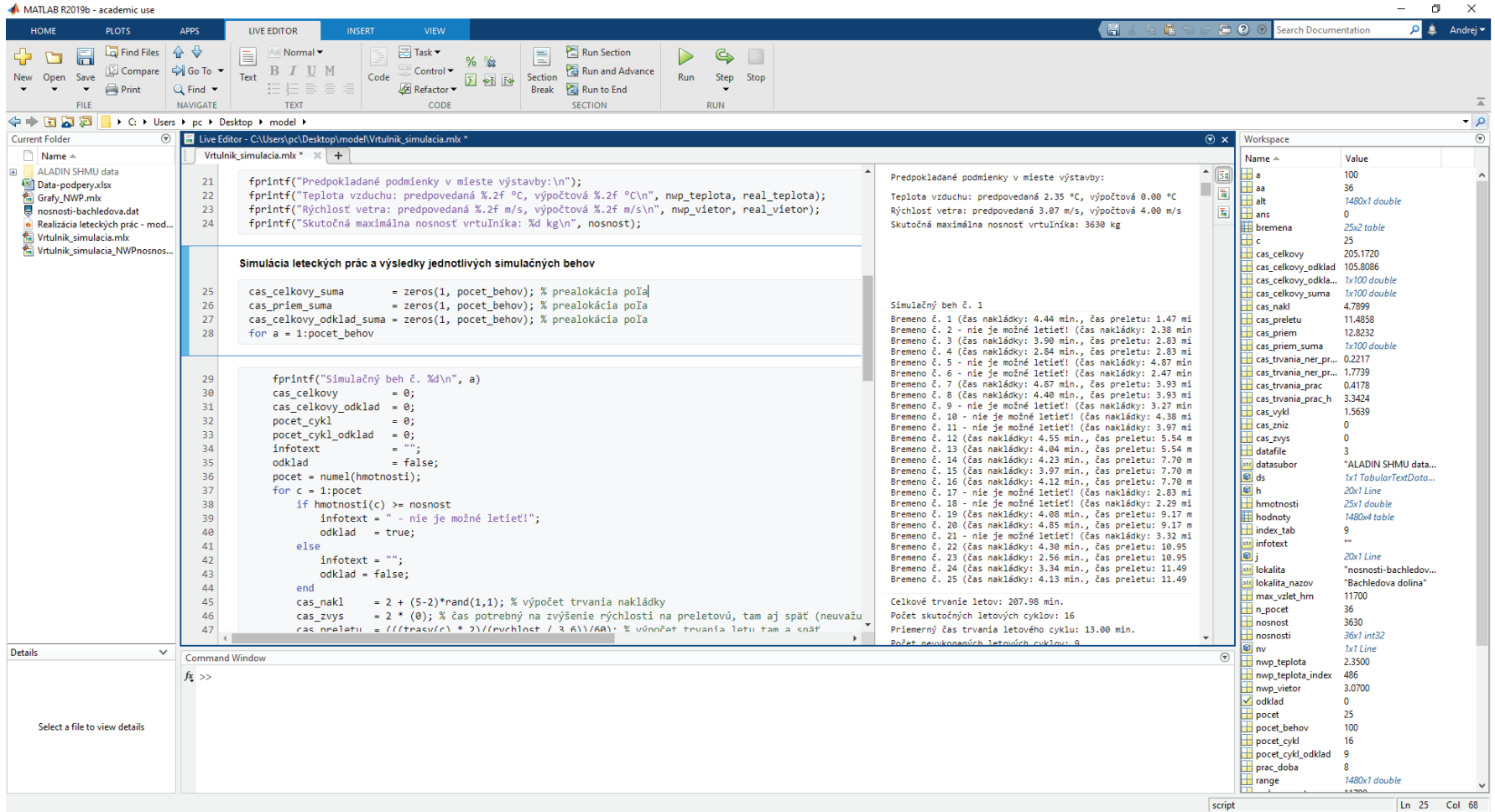

Fig. 2 MATLAB working environment with the proposed simulation model in the form of so-called live script (authors)

The use of the said algorithm core assumes that meteorological data, regardless of the method used to obtain it, is related to a geographical point closest to the construction site under consideration. Thanks to this, the simulation model can provide us with information on whether a helicopter flight is possible on a given day and hour and can inform us about its actual maximum load capacity. It can also provide us with detailed information on the expected duration of the work and its exact progress, including the necessary reserves and other statistical indicators. The numerical weather forecast in Slovakia is provided by the Slovak Hydrometeorological Institute (SHMÚ); we therefore used numerical models provided by this organization in the implementation of our simulation model.

\subsection{Implementation of the Simulation Model Algorithm}

In assessing the relevance and overall impact of environmental factors on the operation of a helicopter, we based them on the knowledge and experience of the aviation practice (Schoř and Šustek 2008; Kadlec 2011). Therefore, in solving our simulation model, we did not consider factors that demonstrate a low or negligible level of significance. For example, we narrowed the issue of head and rear winds (Kadlec 2011) to the general wind speed in accordance with the planning procedures in aviation practice and also in accordance with the possibilities of the numerical weather prediction models used.

Input data with a continuous character, i.e., a nomographic chart of the maximum take-off weight of the helicopter (expressing the dependence of the take-off weight on the air temperature, wind speed, and altitude), as commonly used in aviation practice, was discretized in the required number of points into a three-dimensional matrix. In our region, Mi-8 and Mi-17 helicopters are most often used for aerial work. Due to the simplification of the input data's database, when discretizing the data, we considered only the Mi- 8 helicopter, with which the vast majority of aerial work is performed in Slovakia.
For reasons of simplicity, we have also added other restrictions to the data discretization. We chose the range of the input data with respect to the expected period of use of the proposed simulation model, i.e., for the period from spring to autumn, when aerial work is mostly in progress. The values of the maximum take-off weight of the helicopter were therefore calculated using the following points:

- Air temperature: $0{ }^{\circ} \mathrm{C}, 10^{\circ} \mathrm{C}, 20^{\circ} \mathrm{C}, 30^{\circ} \mathrm{C}$,

- Wind speed: $0 \mathrm{~m} / \mathrm{s}, 2 \mathrm{~m} / \mathrm{s}, 4 \mathrm{~m} / \mathrm{s} .6 \mathrm{~m} / \mathrm{s}, 8 \mathrm{~m} / \mathrm{s}, 10 \mathrm{~m} / \mathrm{s}, 12 \mathrm{~m} / \mathrm{s}$, $14 \mathrm{~m} / \mathrm{s}, 16 \mathrm{~m} / \mathrm{s}$, thereby resulting in a total of 36 possible combinations. For each combination, we then manually read the appropriate value of the maximum take-off weight in accordance with the above nomographic chart. For wider use, it is possible to supplement the matrix with other values, especially negative air temperatures, and to solve the discretization in a larger number of points, which makes the simulation even more accurate.

A key component of the simulation model is obtaining input data from meteorological sources. We designed this part on the basis of several successive steps with a gradual approximation of the data using various numerical weather prediction models from the SHMÚ portfolio. Under stable conditions, a numerical weather prediction is relevant within a maximum of 10 days. For this reason, in this part of the research we proposed an algorithm consisting of 2 steps for planning the implementation of the aerial work a maximum of 10 days before the required date.

For the sake of simplification, our current implementation of the simulation model does not address the entire cableway or the helicopter's entire flight pattern, i.e., it does not include the helicopter's flight from its home airport to the construction site but instead only addresses one important section, i.e., the actual construction site. An essential characteristic of the numerical models used is that their outputs must take into account the values of the air temperature, wind speed, and other parameters at a certain height above the ground, i.e., in the different layers of the atmosphere in which the helicopter moves at work. 
The first step in the proposed algorithm is based on the Integrated Forecasting System (IFS) model and is applied in a range of 3 to 10 days before the scheduled work date. From a technical point of view, in this step we can update the forecast every 12 hours, e.g., at 00:00 and 12:00 UTC (actual outputs related to the stated hours are always available at 07:10 and 19:11 UTC). The atmospheric model is calculated based on a fixed model grid and with defined levels. In each time and space step, we can obtain a three-dimensional profile of the air temperature, wind speed, and air pressure as well as more than 300 other parameters, if necessary.

In the second step, which lasted from 3 days before the scheduled start until the actual time of the start, we began using local models with a higher resolution, i.e., the ALADIN and A-LAEF models (Derková et al. 2017; Termonia et al. 2018). This allowed us to confirm the type of weather predicted and specify the actual date/time and duration of the work. At this point, we were able to re-assess our decision every 6 hours, at 00:00, 06:00, 12:00, and 18:00 UTC or, where so-called rapid update models were used, every 1 to 3 hours. An example of a graphic output from the ALADIN model, i.e., an 'altitude profile' depicting the individual parameters for 0 to $12 \mathrm{~km}$ above the earth's surface, is provided in Fig. 3.

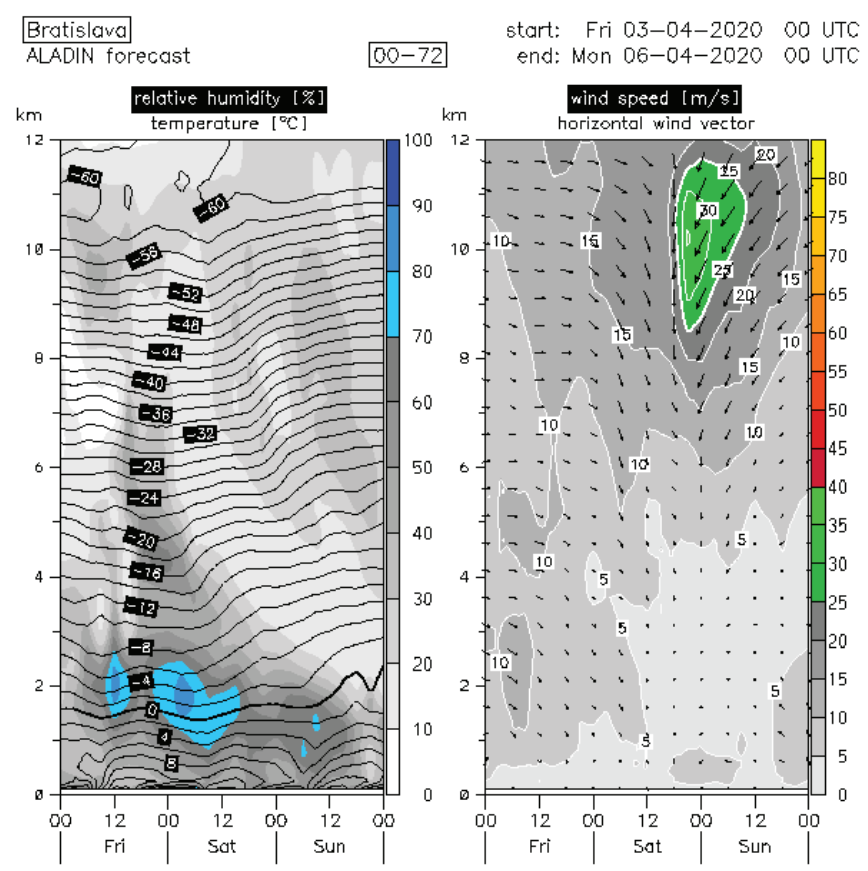

Fig. 3 ALADIN model - example of altitude profile of air temperature, relative humidity, and wind velocity for Bratislavaforecast from 3.4 .2020 to 6.4 .2020 , altitude $0-12 \mathrm{~km}$ (authors)

SHMÚ is a member of the Regional Cooperation for Limited Area Modelling in Central Europe (RC LACE) project; one of its many joint activities is the development of the ALADIN Limited Area Ensemble Forecast (A-LAEF) probabilistic system, which provides suitable information for this step of the proposed simulation model (Wang et al. 2011; Wang et al. 2018; Belluš et al. 2019). The calculations by the 16 members of the ALADIN (ALARO-1) multiphysical model takes place twice a day (00:00 and 12:00 UTC), and the length of the forecast is the above-mentioned 72 hours. In cooperation with SHMÚ, we adapted the outputs from the ALADIN predictive model into a data file in the required format to allow for their use in the simulation model. This gave us discrete data in a machine processable form for our specific grid point (construction site).
The current data file was generated by SHMÚ in the above-specified time interval. Interpretation of the new forecast and how it would affect aerial work was thus simply a matter of running a new simulation model with the relevant data file input. In the case of a broader application of the proposed concept, even in this case more advanced automation could be applied, and the data file could be downloaded and loaded automatically from the forecast provider.

\section{RESULTS}

In this section, we will briefly present the practical results of the use of our proposed simulation model on a typical example of aerial work, i.e., the construction of an aerial cableway in Bachledova dolina, Malá Pol'ana (Slovakia). Construction of this cableway was carried out in 2018. Its developed length is $1518.57 \mathrm{~m}$; the elevation of the route is $264.40 \mathrm{~m}$; and there are 9 tubular steel towers along the line, two of which are directly behind the lower station. The upper station is located at an altitude of $1154.70 \mathrm{~m}$ above sea level. The implementation of this case study was preceded by the verification of the simulation model, which we performed using data from the construction from which we obtained the input data (especially a project involving the construction of three cableways in Szczyrk, Poland). The results of the verification were in line with those at similar construction sites, including historic constructions (Bartoš et al. 1973), and fully confirmed the validity of the proposed model.

\subsection{Input Data}

The heights of the towers of the cableway in question are 11.30 $\mathrm{m}$ to $24.50 \mathrm{~m}$, and their weights are $11,029 \mathrm{~kg}$ to $17,158 \mathrm{~kg}$. Input data on the individual loads (components of the towers), their quantity, and weights were taken from the weight table provided by the cableway manufacturer. We obtained information about the length of the transport route for each load from the drawing of the longitudinal profile of the cableway line and simply determined the transport distance of each load as the so-called length developed between the lower station and the tower under construction. An example of the longitudinal profile drawing of the cableway line, which shows the necessary data, is shown in Fig. 4.

A construction diagram of the towers is shown in Fig. 5. The simulation itself was only performed for the construction section of the towers (pipe shafts); the tower heads, roller batteries, and work platforms forming the technological part of the facility were omitted from the solution. We completely omitted Tower Numbers 1 and 2, which were located immediately at the lower station (Fig. 4 , designated as $\mathrm{C} 1$ and $\mathrm{C} 2$ ), which were fitted with a mobile crane due to their accessibility on the ground. We transported a total of 20 loads. We obtained information about the weather conditions at the expected time of construction in the manner referred to in the concept described in the previous section. For our simulation we used a 72-hour numerical weather forecast based on the SHMÚ ALADIN model of 13.4.2020 06:00 CEST. A graphically interpreted weather forecast by the MATLAB programming environment with the plotting of the actual maximum load capacity of the helicopter is shown in Fig. 6.

The numerical weather forecast used was related from the nearest grid point to the desired point (lower station of the cableway) with the geographic coordinates of $49.271966^{\circ}, 20.309696^{\circ}$. The ALADIN model found 4 network points near the specified coordinate, from which we used Point No. 1 (index 146200) when processing the forecast. This point lies on the geographical coordinates $49.28^{\circ}, 20.33^{\circ}$ at a distance of $1.68 \mathrm{~km}$ from the desired point. 


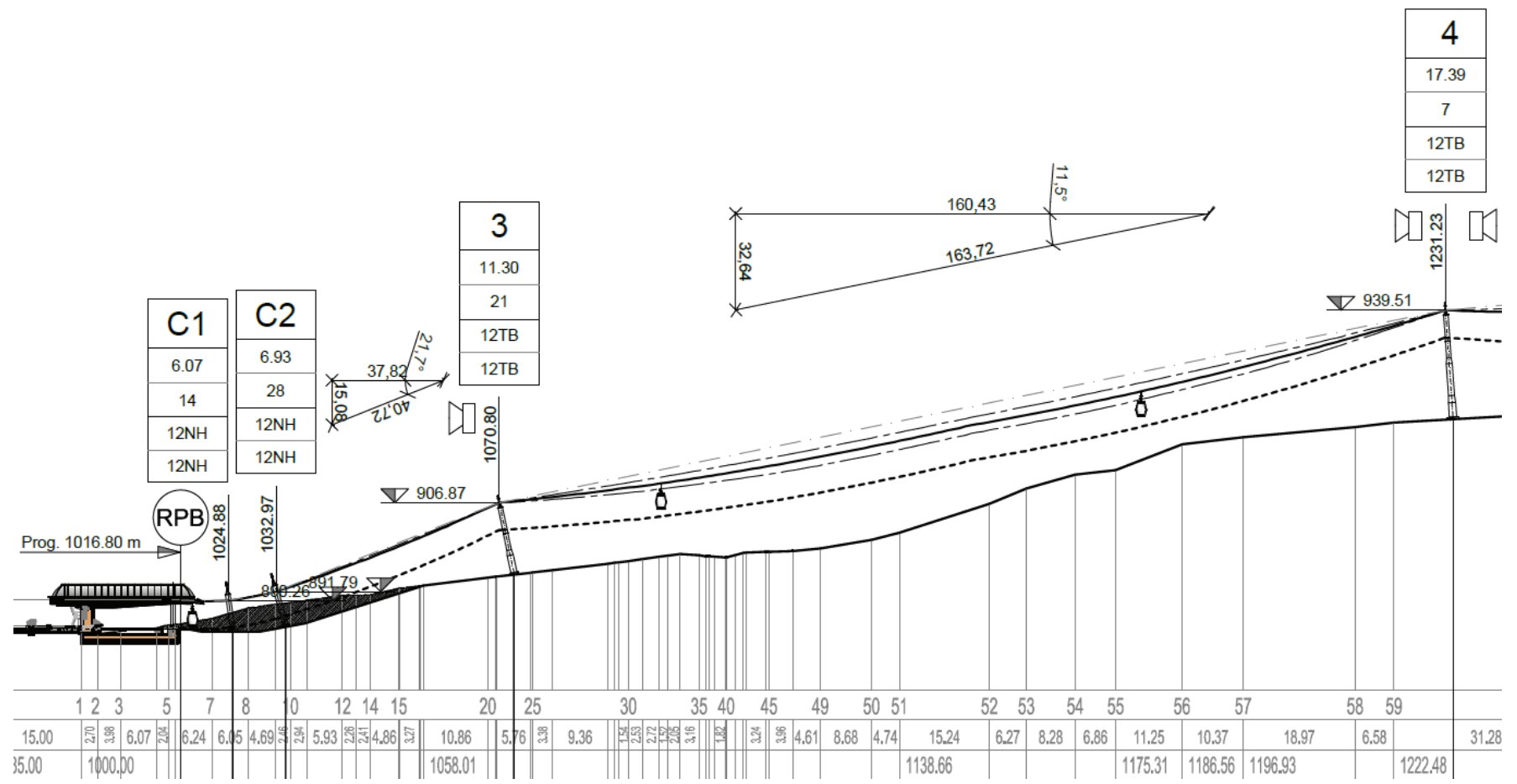

Fig. 4 Part of the longitudinal profile drawing of the Bachledova dolina, Malá Pol'ana cableway

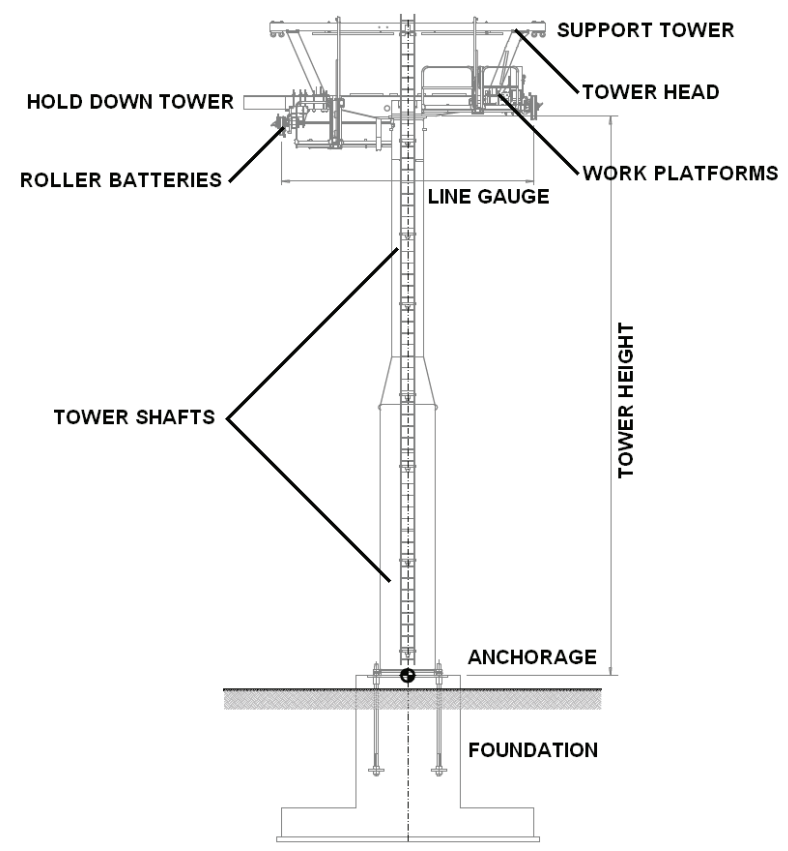

Fig. 5 Construction diagram of towers for Leitner monocable cableways with circulating system (authors)

\subsection{Simulation - Variant 1}

In variant 1 , we scheduled the start of the installation at 50 hours from when the forecast became effective, i.e., 15.4.2020 08:00 CEST. We assumed a standard helicopter transport flight speed of approximately $15 \mathrm{~km} / \mathrm{h}$ and an 8-hour work shift. We performed a total of 150 simulation runs. At the time of the simulativvon, in terms of the output of the simulation model, the follovvvvwing boundary conditions applied to the process:

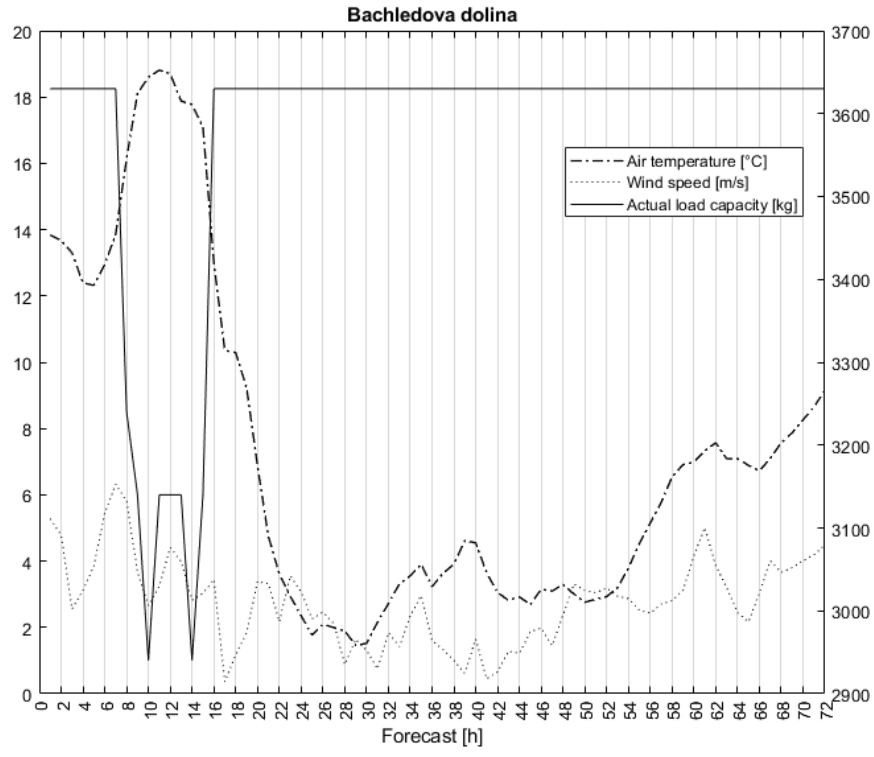

Fig. 6 Interpreted numerical weather forecast of the ALADIN model in the MATLAB environment for the Bachledova dolina locality with a plot of the expected development of the actual maximum load capacity of the helicopter (authors)

- Air temperature: forecast $2.76{ }^{\circ} \mathrm{C}$, calculated at $0.00{ }^{\circ} \mathrm{C}$,

- Wind speed: forecast $3.11 \mathrm{~m} / \mathrm{s}$, calculated at $4.00 \mathrm{~m} / \mathrm{s}$,

- Actual maximum load capacity of the helicopter: $3,630 \mathrm{~kg}$.

The output values from the simulation under the given conditions are given in Tab. 1. 
Tab. 1 Simulation results

\begin{tabular}{llrr}
\hline & & Variant 1 & Variant 2 \\
Avg. time [min] & 229.37 & 155.33 \\
Work duration & Minimum \& maximum [min] & $218.32-242.08$ & $145.97-166.16$ \\
& Standard deviation [min] & 4.49 & 3.85 \\
& Avg. time [min] & 11.47 & 10.36 \\
Flight cycle duration & Minimum \& maximum [min] & $10.92-12.10$ & $9.73-11.08$ \\
& Standard deviation [min] & 0.22 & 0.26 \\
Duration of work backlog & Avg. time [min] & 0 & 73.40 \\
Results & Avg. duration of work [h] & 3.82 & 2.59 \\
& Avg. duration of work backlog [h] & 0 & 1.22
\end{tabular}

\subsection{Simulation - Variant 2}

In variant 2, we expected the installation to start at 10 hours from when the forecast became effective, i.e., 13.4.2020 16:00 CEST. In practical terms, it was highly unlikely that work would begin so late in the afternoon, despite the long hours of daylight in April. It was therefore the aim of this variant to demonstrate the practical effects of various combinations of input values, taking into account the weather forecast that was available at the time of the research. The transport speed of the helicopter, the duration of the work shift, and the number of simulation runs were identical as in variant 1 . At the time of the simulation, in terms of the output of the simulation model, the following boundary conditions applied to the process:

- Air temperature: forecast $18.60^{\circ} \mathrm{C}$, calculated at $20.00{ }^{\circ} \mathrm{C}$,

- Wind speed: forecast $2.66 \mathrm{~m} / \mathrm{s}$, calculated at $2.00 \mathrm{~m} / \mathrm{s}$,

- Actual maximum load capacity of the helicopter: $2,940 \mathrm{~kg}$.

The output values from the simulation under the given conditions are given in Tab. 1 .

\subsection{Discussion}

The results of the construction process differ greatly between the variants, primarily as they concern the duration of the work back$\log$ ( 0 minutes versus 73.40 minutes), which was mainly caused by the changing weather conditions at the construction site. We believe the results obtained from the simulation are reliable, as they are very close to the results achieved in practice with construction of this type, and they fully support the use of simulations in preparing aerial works in construction.

A certain complication could be due to the fact that cableways by their nature belong to linear structures, in which the use of numerical weather prediction models may be associated with some degree of inaccuracy. As mentioned above, numerical prediction models are calculated in a firmly defined grid (resolution). In the case of linear structures, however, we need to obtain predictive data for several construction sites located in close proximity to each other, i.e., for several grid points. In aerial work, this problem mainly occurs in the construction of the above-described cableways, but in a broader sense it is an issue affecting any linear structures, e.g., roads, railways or pipelines.

In these cases, it may happen that the distance of the points where we need to know the weather forecast will be lower than the resolu-

tion of the forecast model used. This means that the relevant forecast for several sites could be related to the same grid point or to another point, which, however, will also be located at a certain distance and altitude from the intended location. However, these differences can generally be considered negligible in practice. In the case of constructions that are carried out in one concentrated place (buildings), this problem does not occur, and the point closest to the construction site is used in the calculations of the model.

\section{CONCLUSIONS}

This article deals with the design and implementation of a simulation model of aerial work, which we have regarded in the broader framework of education aimed at the potential for use of computer simulations for planning this type of construction. A defining part of our simulation model is that it addresses how weather conditions impact the construction; we devised the simulation model algorithm on the basis of various commercially used numerical weather prediction models, such as IFS, ALADIN and A-LAEF.

Based on the knowledge we gained from imaging actual construction processes and the relevant information we learned from construction practices, we designed and built a simulation model for aerial works and demonstrated its potential using the case of the construction of an aerial cableway in Bachledova dolina (Slovakia). At the same time, we presented some possibilities for applying numerical models of weather predictions at the level of present day, which, as such, represent a "simulation model in a simulation model". The proposed simulation model represents (even after possible additions or refinements) a suitable tool for construction practice during the preparation of these types of constructions and increases their efficiency. The concept of the simulation model is open and allows for a broad range of its use throughout the construction sector as well as in other branches of industry.

\section{Acknowledgements}

The authors thank Leitech, s.r.o., Bratislava (Leitner Ropeways) and UTair Europe, s.r.o., Bratislava for their cooperation. Part of the research was carried out thanks to a financial grant from the Program for the Support of Young Researchers of STU in Bratislava in 2018. This paper was created as a research work for VEGA Project No. $1 / 0511 / 19$. 


\section{REFERENCES}

AbouRizk, S. (2010) Role of simulation in construction engineering and management. Journal of Construction Engineering and Management, 136(10), pp. 1140-1153.

AbouRizk, S. et al. (2011) Research in modeling and simulation for improving construction engineering operations. Journal of Construction Engineering and Management, 137(10), pp. 843-852.

Alsudairi, A. A. (2015) Simulation as a tool for assessing the economical aspects of construction processes. Procedia Engineering, 118, pp. 1086-1095.

Bartoš, R. et al. (1973) Vrtulniky při stavebně-montážních pracech a transportu materiálu. Sborník prednášek. Pardubice: Dom techniky ČVTS Pardubice (in Czech).

Belluš, M. et al. (2019) Aire Limitée Adaptation Dynamique Développement InterNational - Limited Area Ensemble Forecasting (ALADIN-LAEF). Advances in Science and Research: Contributions in Applied Meteorology and Climatology, 16, pp. 63-68.

Bisták, A. (2017) Simulácia stavebných procesov realizovaných vrtul'nikmi: analýza a návrh koncepcie modelu (Simulation of construction processes carried out by helicopters: analysis and design of the model concept). In: Advances in Architectural, Civil and Environmental Engineering: 27th Annual PhD Student Conference, 2017, Bratislava, Slovakia. Bratislava: Spektrum STU, pp. 226-231. ISBN 978-80-227-4751-6 (in Slovak).

Bisták, A. (2018) Využitie simulačného modelovania pri príprave výstavbového procesu realizovaného technológiou leteckých prác (The use of simulation modeling in construction-technological preparation for aerial works). In: Advances in Architectural, Civil and Environmental Engineering: 28th Annual PhD Student Conference, 2018, Bratislava, Slovakia. Bratislava: Spektrum STU, pp. 115-122. ISBN 978-80-227-4864-3 (in Slovak).

Derková, M. et al. (2017) Recent improvements in the ALADIN/SHMU operational system. Meteorological Journal, 20(2), pp. 45-52.

Dosoudil, E. et al. (1971) Létající jeřáby. Sbornik přednášek. Pardubice: Transporta, n.p. Chrudim and Dom techniky ČVTS Pardubice (in Czech).

Fedorko, G. - Honus, S. - Badiarová, S. (2017) Analysis of the utilization of machinery in the production process using computer simulation. MATEC Web of Conferences, 134.

Hrubeš, V. (1988) Využiti vrtulniků v osmdesátých letech v ČSSR. In: Využitie vrtulnikov v národnom hospodárstve - zbornik prednášok, Tatranská Lomnica, 18. - 19.10.1988. Žilina: Dom techniky ČSVTS v Žiline, pp. 16-19 (in Czech).

Hulínová, Z. (2011) Analýza stavebných procesov z hladiska ich modelovania (Analysis of the construction process in terms of modeling). Bratislava: Nakladatel'stvo STU. ISBN 978-80-2273474-5 (in Slovak).

Jindra, F. (1965) Stavebně montážní práce s využitím vrtulníků $v$ ČSSR. Prague: NADAS (in Czech).

Jung, M. et al. (2016) Weather-delay simulation model based on vertical weather profile for high-rise building construction. Journal of Construction Engineering and Management, 142(6).
Jung, M. et al. (2017) Construction worker hoisting simulation for sky-lobby lifting system. Automation in Construction, 73, pp. 166174.

Kadlec, M. (2011) Výkonnost - vrtulniky (034 00). Učebni texty dle předpisu JAR-FCL 2. Brno: Akademické nakladatelství CERM. ISBN 978-80-7204-687-4 (in Czech).

Lee, S. et al. (2013) Grand challenges in simulation for the architecture, engineering, construction, and facility management industries. In: Computing in Civil Engineering - Proceedings of the 2013 ASCE International Workshop on Computing in Civil Engineering. American Society of Civil Engineers, pp. 773-785. ISBN 978-078447790-8.

Lindhard, Sø. M. et al. (2019) Impact of activity sequencing on reducing variability. Journal of Construction Engineering and Management, 145(3).

Mačková, D. et al. (2017) Construction-duration prediction model for residential buildings in Slovak Republic based on computer simulation. International Journal of Applied Engineering Research, 12(13), pp. 3590-3599.

Mahmoodzadeh, A. - Zare, S. (2016) Probabilistic prediction of expected ground condition and construction time and costs in road tunnels. Journal of Rock Mechanics and Geotechnical Engineering, 8(5), pp. 734-745.

Martinez, J. (2010) Methodology for conducting discrete-event simulation studies in construction engineering and management. Journal of Construction Engineering and Management, 136(1), pp. 3-16.

Messingerová, V. (2005) Technológia vzdušnej dopravy dreva $\mathrm{v}$ lesnictve (Technology of air transport of wood in forestry). Zvolen: Technická univerzita vo Zvolene. ISBN 80-228-1523-3 (in Slovak).

Muhabie, T. Y. et al. (2018) A discrete-event simulation approach to evaluate the effect of stochastic parameters on offshore wind farms assembly strategies. Ocean Engineering, 149, pp. 279-290.

Schoř, J. - Šustek, P. (2008) Hmotnost a vyváženi - vrtulníky (031 00). Učebni texty dle předpisu JAR-FCL 2. Brno: Akademické nakladatelství CERM. ISBN 978-80-7204-597-6 (in Czech).

Termonia, P. et al. (2018) The ALADIN system and its canonical model configurations AROME CY41T1 and ALARO CY40T1. Geoscientific Model Development, 11(1), pp. 257-281.

Wang, Y. et al. (2011) The Central European limited-area ensemble forecasting system: ALADIN-LAEF. Quarterly Journal of the Royal Meteorological Society, 137(655), pp. 483-502.

Wang, Y. et al. (2018) 27 years of regional cooperation for limited area modelling in Central Europe. Bulletin of the American Meteorological Society, 99(7), pp. 1415-1432. 